\title{
Transplanting Coral Fragments in Close Contact Enhances Their Survival and Growth on Seawalls
}

\author{
Yuichi Preslie Kikuzawa ${ }^{1, *}$, Chin Soon Lionel $\mathrm{Ng}^{1}{ }^{1}$, Shu Qin Sam ${ }^{1}$, Tai Chong Toh ${ }^{1,2}$, Koh Siang Tan ${ }^{1}$, \\ Poh Leong Loo ${ }^{1}$ and Loke Ming Chou ${ }^{1,3}$
}

1 Tropical Marine Science Institute, National University of Singapore, 14 Kent Ridge Road, Singapore 119223, Singapore; lionelng@nus.edu.sg (C.S.L.N.); tmsssq@nus.edu.sg (S.Q.S.); taichong.toh@nus.edu.sg (T.C.T.); tmstanks@nus.edu.sg (K.S.T.); tmslpl@nus.edu.sg (P.L.L.); tmsclm@nus.edu.sg (L.M.C.)

2 College of Alice \& Peter Tan, National University of Singapore, 8 College Avenue East, Singapore 138615, Singapore

3 Department of Biological Sciences, National University of Singapore, 16 Science Drive 4, Singapore 117558, Singapore

* Correspondence: kikuzawa@nus.edu.sg

Citation: Kikuzawa, Y.P.; $\mathrm{Ng}$, C.S.L.; Sam, S.Q.; Toh, T.C.; Tan, K.S.; Loo, P.L.; Chou, L.M. Transplanting Coral Fragments in Close Contact Enhances Their Survival and Growth on Seawalls. J. Mar. Sci. Eng. 2021, 9, 1377. https://doi.org/10.3390/ jmse9121377

Academic Editor: Tom Spencer

Received: 22 October 2021

Accepted: 2 December 2021

Published: 3 December 2021

Publisher's Note: MDPI stays neutral with regard to jurisdictional claims in published maps and institutional affiliations.

Copyright: () 2021 by the authors. Licensee MDPI, Basel, Switzerland. This article is an open access article distributed under the terms and conditions of the Creative Commons Attribution (CC BY) license (https:// creativecommons.org/licenses/by/ $4.0 /)$.

\begin{abstract}
Accelerated urbanisation has replaced many natural shorelines with coastal defences, resulting in the loss of natural habitats. However, structures such as seawalls can support some biotic assemblages, albeit of lower species richness. Ecological engineering techniques such as coral transplantation can enhance biodiversity on these artificial structures, but its success is circumscribed by high costs. Little is known about the fusion of discrete coral colonies that could potentially improve coral transplantation success on seawalls, particularly for the slow-growing massive species that are generally well-adapted to living on seawalls. Here, we investigated the feasibility and cost-effectiveness of transplanting Platygyra sinensis on seawalls by comparing the survivability and growth of fragments transplanted adjoining with those transplanted further apart. Fragments (approximately $3 \mathrm{~cm}$ diameter; $n=24$ ) derived from three individuals were randomly grouped into two treatments, transplanted at $0.5 \mathrm{~cm}$ and $5 \mathrm{~cm}$ apart. Fragments in the former treatment came into contact with each other after three months. We observed that in all cases, the contact zones were characterised by a border of raised skeletal ridges without tissue necrosis, often termed nonfusion (=histoincompatible fusion). The adjoining transplants showed better survival (75 vs. $43 \%$ ) and grew at a rate that was significantly higher than fragments transplanted $5 \mathrm{~cm}$ apart $(3.7 \pm 1.6 \mathrm{vs}$. $0.6 \pm 1.1 \mathrm{~cm}^{2}$ month $\left.^{-1}\right)$. Our projections demonstrated the possibility of reducing transplantation $\operatorname{cost}\left(\mathrm{USD} \mathrm{cm}^{-2}\right)$ by $48.3 \%$ through nonfusion. These findings present nonfusion as a possible strategy to increase the overall cost-effectiveness of transplanting slow-growing massive species on seawalls.
\end{abstract}

Keywords: coral transplantation; ecological engineering; coral growth; coral survivorship; contact reaction; massive corals; coral fusion; Singapore

\section{Introduction}

The world's natural coastlines are increasingly replaced with artificial structures such as groynes, breakwaters and more commonly, seawalls that primarily serve to defend the coast [1]. These structures mitigate the risks of flooding [2] while protecting infrastructures from coastal erosion and wave impact [3,4]. However, this has also resulted in the extensive loss of coastal habitats such as seagrass meadows, mangroves and coral reefs, along with the associated biodiversity and ecosystem functions. In spite of these impacts, studies have recently documented how artificial structures can provide habitats to molluscs [5], corals [6-9] and fish [10-12], although some biotic assemblages can be less diverse compared to their natural counterparts $[9,12,13]$. As it is crucial to preserve the myriad ecosystem services that human communities are reliant on, strategies such as 
ecological engineering, which aim to enhance biodiversity on artificial structures such as seawalls, are increasingly being studied see [14-17]. One of the developing approaches in ecological engineering is coral transplantation see [16-18], a technique that is commonly employed in reef restoration $[19,20]$.

A primary goal of coral transplantation is to quickly increase the amount of live coral cover at degraded reefs [21]. Thus, although massive corals are more resilient to physical impacts [22-24] and thermal stress [25-27], most transplantation efforts disproportionately focus on branching coral species [22] such as acroporids and pocilloporids, which are fastgrowing and can be easily propagated to generate large areas of coral cover [28,29]. Among coral species that were transplanted on seawalls, branching and plating corals did not seem to survive well $[17,19]$, while transplants of massive species on both subtidal $[17,30]$ and intertidal seawalls [19] were observed to survive better than their branching counterparts. Greater fluctuations in environmental parameters such as temperature [31,32] and wave motion $[33,34]$ in the vicinity of seawalls appear to be more stressful to branching corals. Recent studies have shown that more massive species were found naturally on seawalls than branching species $[8,35,36]$. Nevertheless, knowledge gaps exist in the enhancement of coral cover on seawalls. It is therefore important to develop and refine techniques that improve the growth and survivorship of massive coral transplants, so as to maximise the success of ecological engineering efforts [18].

Fusion, defined as segments of coral colonies in contact [37], could represent a scalable method of enhancing coral cover on seawalls since studies have shown that it can accelerate coral growth $[22,37,38]$. Fusion can be divided into two groups, histocompatible and histoincompatible reactions. The former refers to complete fusion: characterised as continuous skeleton and tissue across the contact area, while the latter is subdivided into nonfusion and rejection [39]. Nonfusion occurs where tissues of corals in contact are demarcated by a border of sutures (raised skeletal ridges) without tissue necrosis [40]; rejection occurs where tissue necrosis is present at the zone of contact, which is subsequently colonised by algae $[40,41]$. Fusion between isogeneic (i.e., same parent) juveniles resulted in increased colony size and a greater number of polyps than allogeneic (i.e., different parent) pairs, thus bolstering both the survivorship and growth of small coral colonies [38]. Additionally, isogeneically fused fragments of Acropora millepora (Ehrenberg, 1834) [42], Pocillopora damicornis (Linnaeus, 1758) [38] and Stylophora pistillata (Esper, 1797) [39] exhibited faster growth and lower mortality than individual fragments. Additionally, juveniles of Montipora capitata (Dana, 1846) that aggregated were more resilient against bleaching than those that were solitary [39], suggesting that physical contact between conspecific coral fragments could confer benefits beyond increased growth, survivorship and bleaching resilience. Research on fusion has largely focused on coral spats or juveniles of branching coral genera such as Pocillopora and Seriatopora see [38,40,43]. In comparison, less is known on the effects of fusion on the fragments of massive coral species, as well as whether such an approach has the potential to augment coral transplant growth, and consequently, ecological engineering outcomes.

Because transplantation can be costly $[17,44-46]$, it is also important to assess the variability in biological responses that arise from employing a new ecological engineering technique such as coral fusion, so that the cost-effectiveness of such an approach can be optimised [46]. Toh et al. showed that providing Artemia to juvenile corals resulted in improved post-transplantation growth and survivorship, as well as greater cost-effectiveness [44]. There are, however, few studies projecting or comparing cost breakdowns between alternative strategies in ecological engineering $[17,44-46]$. For example, it was demonstrated that labour cost was substantially reduced through volunteer-driven coral nursery maintenance [17] and that transplanting only small coral fragments $(2-4 \mathrm{~cm})$ could result in greater return-on-effort given limited coral source material [30]. These thought experiments can aid in identifying strategies that represent the best use of limited resources [45] and are increasingly crucial given the growing acceptance and implementation of ecological engineering techniques in coastal development see [15-18,45,47-49]. 
This study seeks to evaluate the feasibility of histoincompatible coral fusion as a technique to improve the success of transplanting fragments of Platygyra sinensis (Milne Edwards and Haime, 1849), a massive species frequently found on seawalls [8] and commonly used in reef restoration and ecological engineering initiatives $[17,30]$. Here, we compared the survivorship and growth of fragments of $P$. sinensis transplanted in close contact ("adjoining") with those transplanted apart ("separate"). We hypothesised that fusion between adjoining transplants would lead to significantly greater growth and survivorship than transplants that were placed separately. What-if scenarios were also conceived in this study to assess how transplantation protocols and decision-making could be augmented through cost estimates in ecological engineering [50]. Subsequently, we estimated the costeffectiveness of coral fusion to determine its economic viability for coral transplantation efforts. The findings of this study will augment ecological engineering initiatives, especially for slow-growing massive coral species.

\section{Materials and Methods}

Twenty four fragments of $P$. sinensis that were reared for at least six months in flow-through aquarium tanks at the St. John's Island National Marine Laboratory were transplanted subtidally on a sloping seawall at Lazarus Island, Singapore $\left(1^{\circ} 13.37^{\prime} \mathrm{N}\right.$, $103^{\circ} 51.08^{\prime} \mathrm{E}$; Figure 1). The fragments originated from three parent colonies that were at least $15 \mathrm{~m}$ apart to ensure genetic diversity. All fragments were approximately $3 \mathrm{~cm}$ in maximum diameter. In order to investigate the effect of fusion on growth and survivorship of $P$. sinensis transplants, 12 fragments were each assigned to two treatments: adjoining (transplanted approximately $0.5 \mathrm{~cm}$ apart from two other fragments in a cluster) and separate (See Figure 2a,c) (transplanted $5 \mathrm{~cm}$ apart from two other fragments in a cluster). Each treatment comprised four clusters of three fragments. Fragments in each cluster were all from different parent colonies. The initial area of fragments did not differ significantly between treatments $(F=0.48, p>0.05)$. Transplants were secured onto granite boulders on the seawall at approximately $-2 \mathrm{~m}$ (Chart Datum), using marine epoxy.

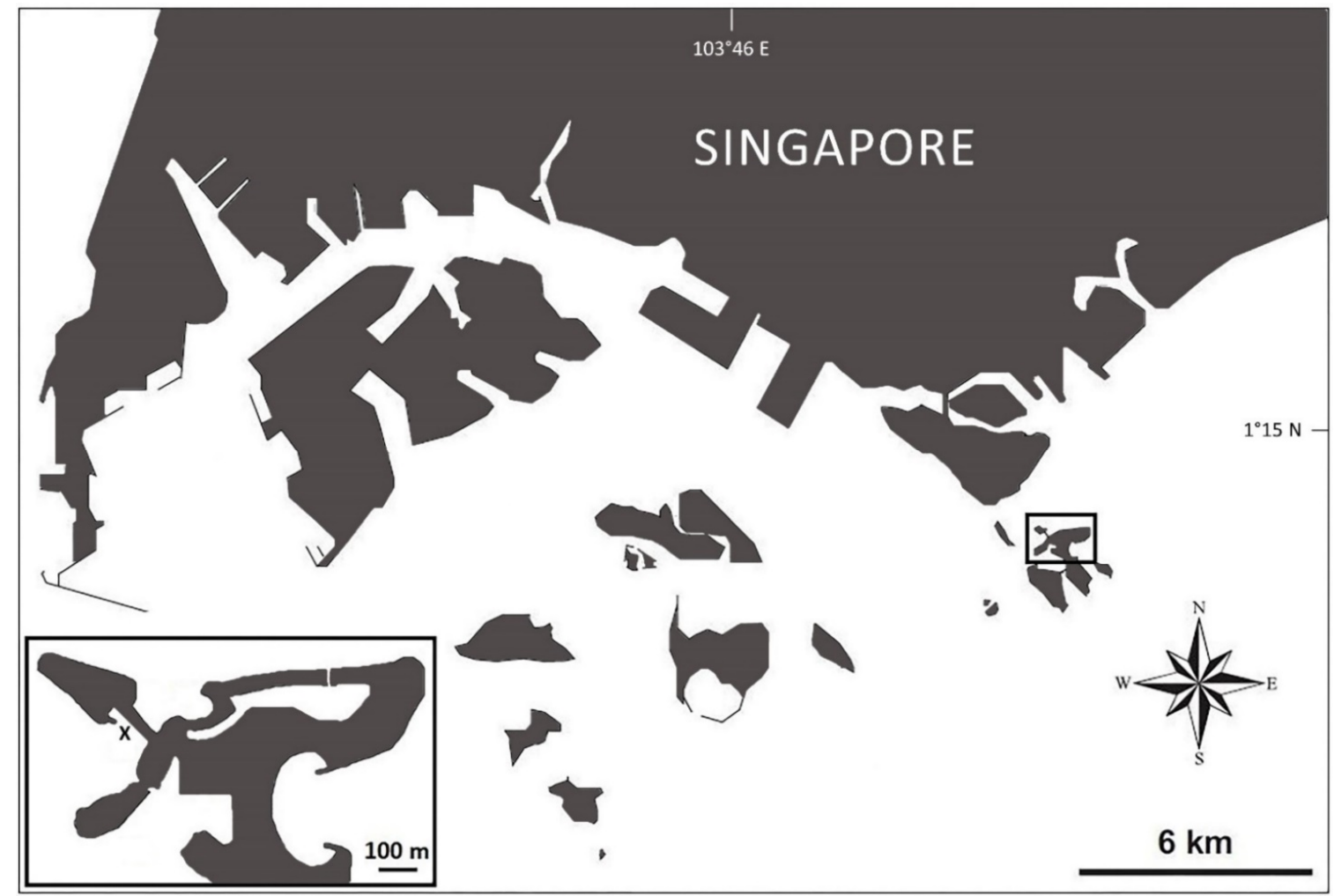

Figure 1. Map of mainland Singapore with the study site (marked " $x$ ") located at Lazarus Island (inset). 


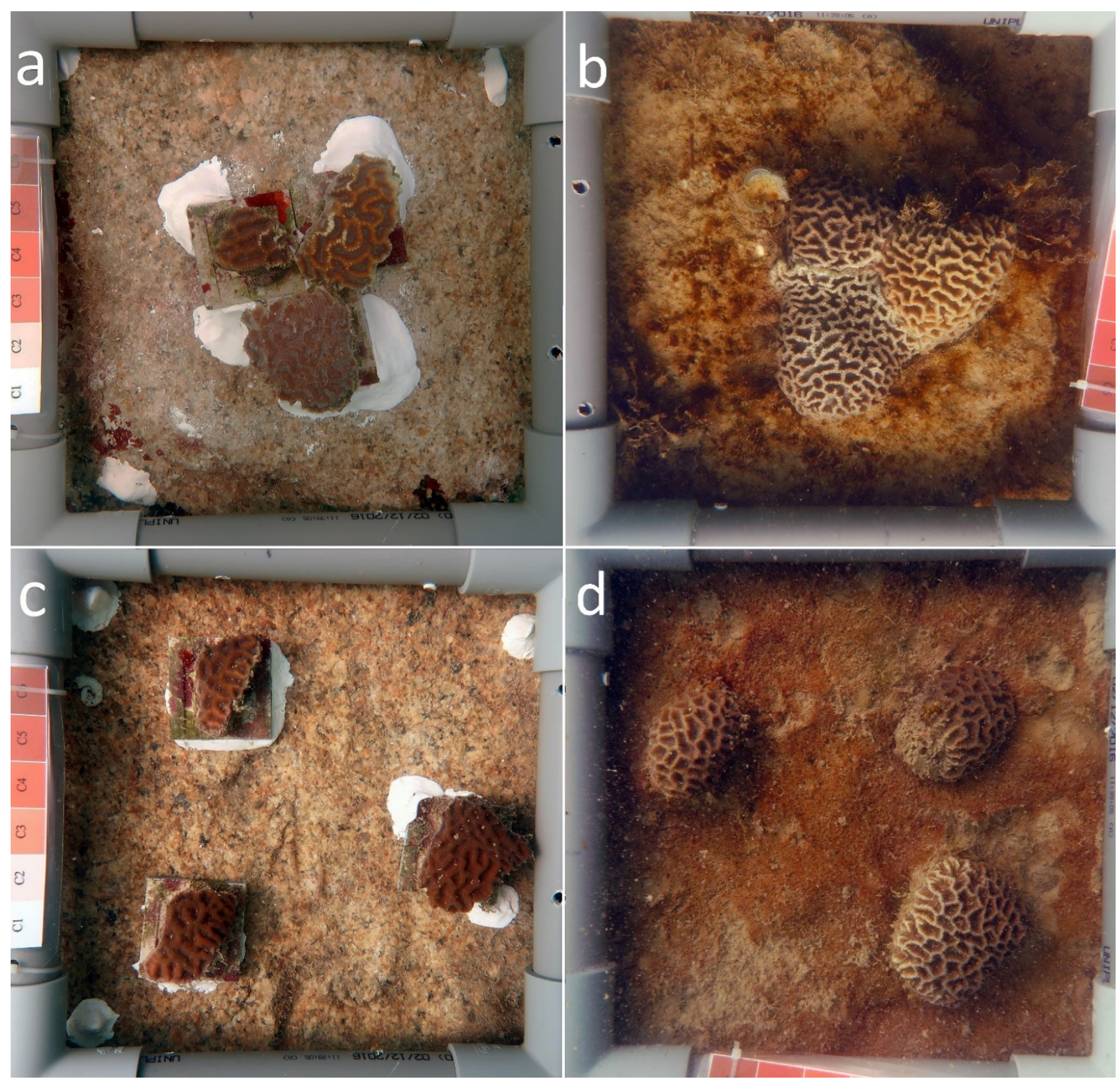

Figure 2. Representative fragments of Platygyra sinensis, transplanted approximately $0.5 \mathrm{~cm}$ apart at month 0 (a) and month 12 (b), transplanted approximately $5 \mathrm{~cm}$ apart at month 0 (c) and month $12(\mathbf{d})$. Length of each coloured square $=2 \mathrm{~cm}$.

Survivorship and live tissue area of the transplants were monitored monthly for 16 months by photogrammetry, a simple and accurate method for tracking two-dimensional changes in coral growth, as previously described by Kikuzawa et al. [51]. Each transplant was individually photographed from a top-down angle with a scale bar, using an Olympus TG-5 camera, and subsequently processed with the ImageJ software (NIH). The increase in live tissue area was monitored as a proxy of coral growth. Transplants that were detached or had $>95 \%$ dead tissue were considered "dead".

\subsection{Statistical Analysis}

After fragments in the adjoining treatment came into contact over the course of the study, the live tissue area of fragments from both treatments was subsequently measured 
as a single mass for each cluster $(n=4)$. Survivorship of the transplants in both treatments was examined with Kaplan-Meier survival analysis and compared with log-rank (MantelCox) tests. To compare differences in growth between adjoining and separate treatments, one-way ANOVA and post-hoc tests using the Tukey's test and Bonferroni correction were performed, after fulfilling the assumptions of normality and homogeneity of variance. All analyses were conducted using SPSS Statistics (Version 21, IBM).

\section{2. "What-If?" Scenarios for Improved Cost Effectiveness}

"What-if?" scenarios were formulated to predict the estimated cost of live coral area generated when fragments were transplanted based on two hypothetical scenarios: adjoining and separate. Each scenario entailed the collection of $1000 \mathrm{~cm}^{2}$ of coral material, fragmentation into 100 fragments of $9 \mathrm{~cm}^{2}$ each with the assumption of up to $10 \%$ of coral material lost as wastage see [30], transplantation of fragments in adjoining and separate designs respectively, as well as monitoring and maintenance of the transplants for a year. The projected coral tissue area after one year was computed:

$$
\text { Projected live tissue area }=(\mathrm{G}+\mathrm{I}) \times \mathrm{N} \times \mathrm{S}
$$

where $G=$ tissue growth in a year $\left(\mathrm{cm}^{2}\right), I=$ initial tissue area $\left(\mathrm{cm}^{2}\right), \mathrm{N}=$ number of fragments or clusters, and $S=$ mean survivorship. The calculation for the cost per unit area of coral was adapted from Toh et al. [16], as the transplantation technique used was similar. The projected total live tissue area after one year was based on the results from the current study (see Supplementary Table S1). Costs were estimated in Singapore dollars (SGD) prior to conversion to USD at the rate of SGD $1.33=$ USD 1.

\section{Results}

In the adjoining treatment, fragments all came into contact during the third month and continued to increase in size until the end of the study (Figure 2). No signs of rejection (i.e., tissue mortality) were observed after contact (Figure 3). Upon close examination, fragments in the adjoining treatment were regarded as exhibiting a nonfusion contact response since this response was previously reported $[40,41]$. On the eighth month, sutures had begun to form at the contact areas. In the 15th month, some of these sutures became raised and progressed to grow over another fragment (Figure 3).
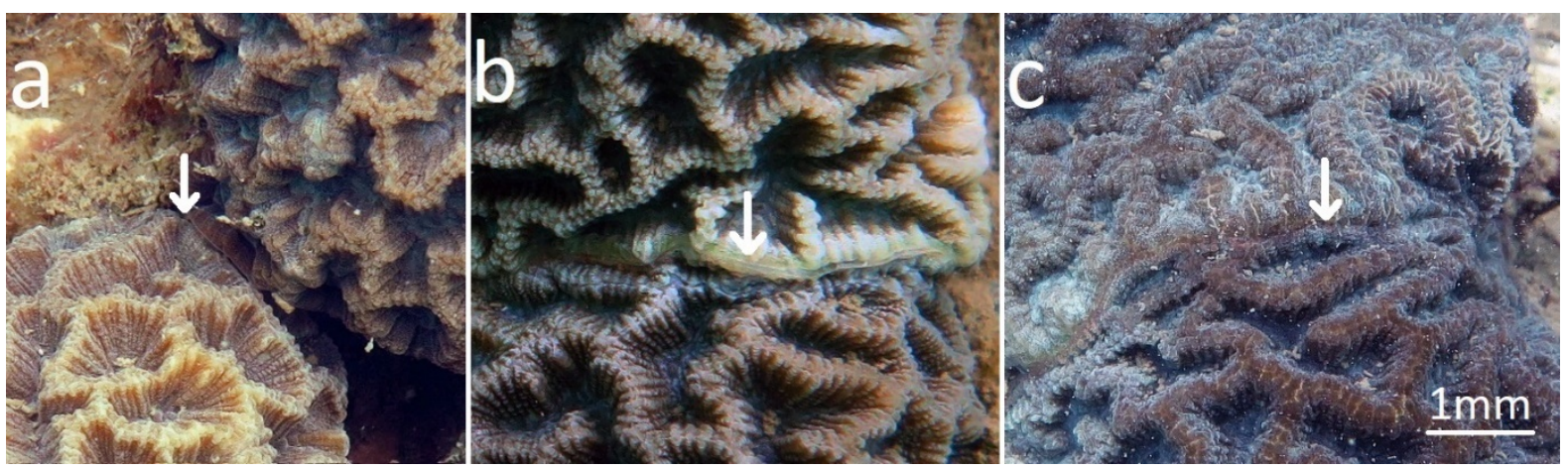

Figure 3. Fragments of Platygyra sinensis exhibiting responses associated with nonfusion, indicated by arrows. (a) Neither tissue rejection nor mortality was observed upon contact at Month 3; (b) nonfusion and raised suture formation between two fragments at Month 8; (c) overgrowth of the top transplant over the bottom observed at Month 15.

After 16 months, fragments in the adjoining and separate treatments registered $75.0 \%$ $(n=4)$ and $42.7 \%$ survivorship respectively $(n=12$; Figure 4$)$. While the survivorship of both treatments decreased sharply during the eighth month, survivorship in the separate treatment subsequently decreased again during the 11th month. After a year, the survivorship of both adjoining and separate fragments stabilized until the end of the study period (Figure 4). 


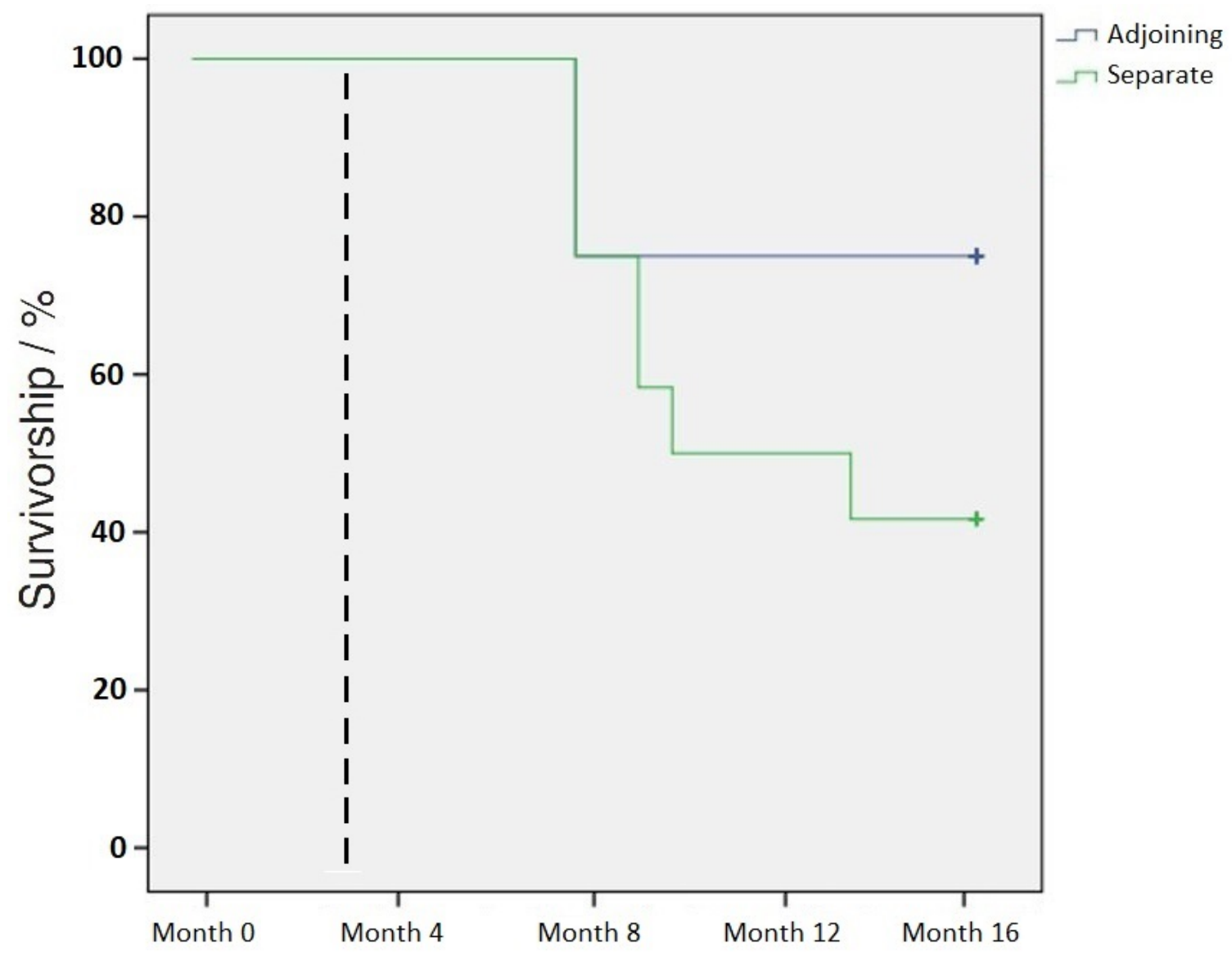

Figure 4. Mean survivorship (\%) of adjoining and separate treatments of Platygyra sinensis across 16 months. Dotted line indicates when contact occurred between fragments in the adjoining treatment.

Although the mean live tissue area of clusters in both treatments increased, the average monthly increase in the live tissue area of adjoining transplants was more than five times that of the separated transplants (Table 1). The average monthly increase in the live tissue area of adjoining transplants $\left(3.74 \pm 1.58 \mathrm{~cm}^{2} \mathrm{mth}^{-1}\right)$ was significantly greater $(\mathrm{F}=7.66$, $p=0.05)$ than that of separated transplants $\left(0.63 \pm 1.13 \mathrm{~cm}^{2} \mathrm{mth}^{-1}\right)$. The total live tissue area of adjoining and separated transplants after 16 months was $291.4 \mathrm{~cm}^{2}$ and $160.1 \mathrm{~cm}^{2}$ respectively (Table 1). Between Month 5 to Month 8, monitoring was suspended due to unexpectedly high levels of turbidity and sedimentation at the study site, resulting in poor visibility and large deposits of silt on the transplants. Interestingly, we observed that less sediment had accumulated on the adjoining transplants than on the separated transplants (Figure 5). The survivorship of separated transplants decreased sharply after Month 8 and continued to decline, while that of adjoining transplants remained constant (Figure 4). Tissue damage from Drupella spp. (Gastropoda) or Scaridae was not observed in this study. 
Table 1. Mean live tissue area, monthly areal growth $( \pm \mathrm{SD})$ and total live tissue area of clusters of Platygyra sinensis, 16 months after transplantation.

\begin{tabular}{|c|c|c|c|c|c|}
\hline Treatments & $\begin{array}{c}\text { Initial Mean Live } \\
\text { Tissue Area } \\
\left(\mathrm{cm}^{2} ; \pm \text { SD) }\right.\end{array}$ & $\begin{array}{c}\text { Final Mean Live } \\
\text { Tissue Area } \\
\left(\mathrm{cm}^{2} ; \pm \text { SD) }\right.\end{array}$ & $\begin{array}{l}\text { Mean Monthly } \\
\text { Areal Growth (cm }{ }^{2} \\
\text { mth }^{-1} ; \pm \text { SD) }\end{array}$ & $\begin{array}{l}\text { Total Initial Live } \\
\text { Tissue Area }\left(\mathrm{cm}^{2}\right)\end{array}$ & $\begin{array}{l}\text { Total Final Live } \\
\text { Tissue Area }\left(\mathrm{cm}^{2}\right)\end{array}$ \\
\hline Adjoining $(n=4)$ & $38.44 \pm 3.41$ & $97.13 \pm 23.27$ & $3.74 \pm 1.58$ & 153.78 & 291.40 \\
\hline Separate $(n=4)$ & $41.53 \pm 4.79$ & $53.37 \pm 16.92$ & $0.63 \pm 1.13$ & 166.13 & 160.10 \\
\hline
\end{tabular}

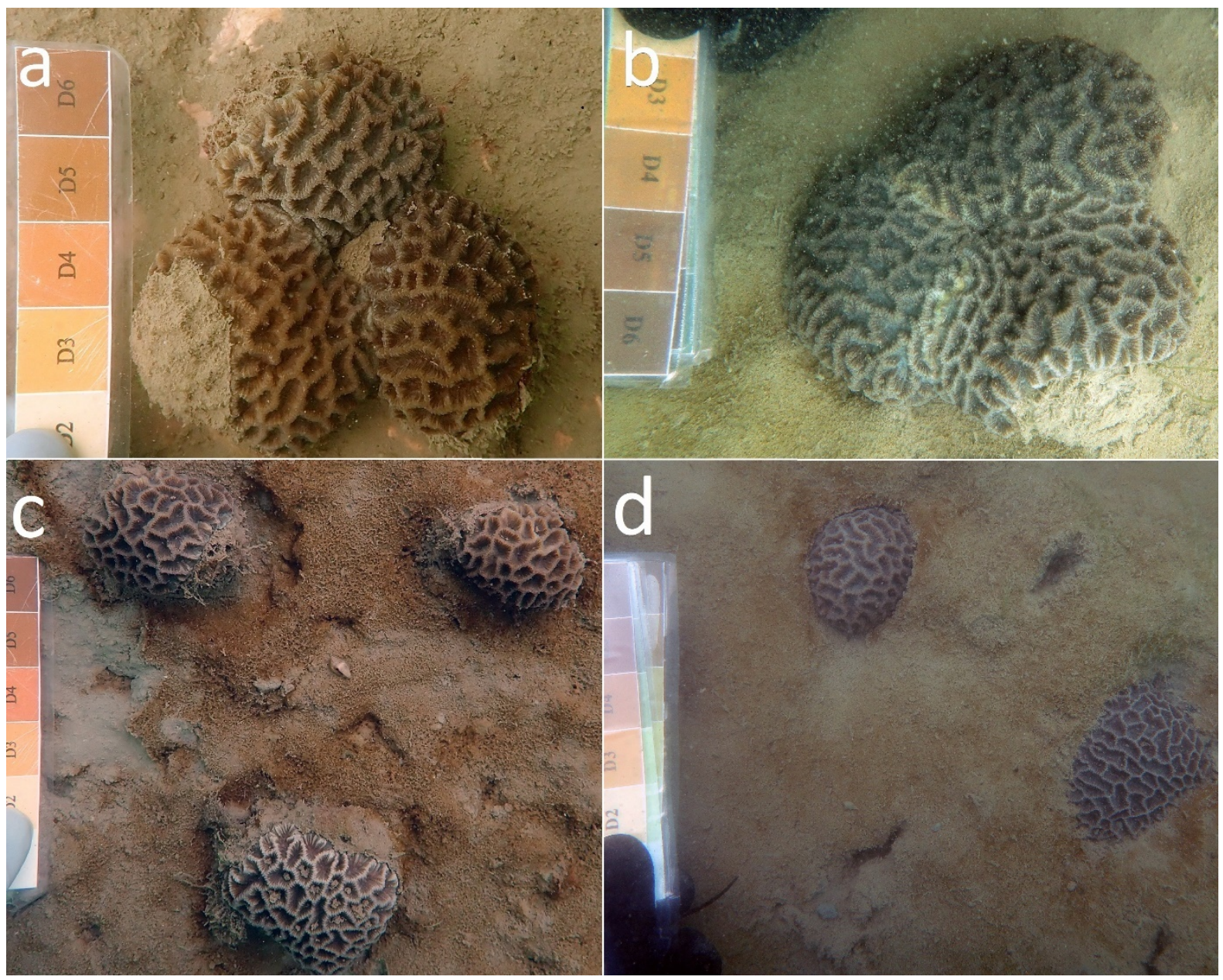

Figure 5. Representative fragments of Platygyra sinensis affected by the highly sedimented conditions at the study site: adjoining transplants in (a) Month 9 and (b) Month 15; separated transplants in (c) Month 9 and (d) Month 15. Length of each coloured square $=2 \mathrm{~cm}$.

The "what-if" scenarios showed that the cost per $\mathrm{cm}^{2}$ of coral transplanted could be minimised to US\$ 6.49 if all transplants were adjoining to promote nonfusion among the P. sinensis fragments (Table 2). In scenario 1 (adjoining), the cost per $\mathrm{cm}^{2}$ of coral projected was reduced by $48.3 \%$ as compared to scenario 2 (separate). 
Table 2. Cost estimates (in USD) of transplanting coral fragments adjoining to promote nonfusion (Scenario 1, "adjoining") versus transplanting fragments apart (Scenario 2, "separate").

\begin{tabular}{|c|c|c|c|}
\hline Description & Remarks & $\begin{array}{c}\text { Scenario } 1 \\
\text { (Adjoining) }\end{array}$ & $\begin{array}{l}\text { Scenario } 2 \\
\text { (Separate) }\end{array}$ \\
\hline $\begin{array}{c}\text { Cost of collecting of source } \\
\text { material }\end{array}$ & $\begin{array}{l}10 \text { colonies of } 100 \mathrm{~cm}^{2} \\
\text { each }\end{array}$ & 667.25 & 667.25 \\
\hline Cost of transplantation & $\begin{array}{l}100 \text { fragments of } 9 \mathrm{~cm}^{2} \\
\text { each } \\
\text { (assuming } 10 \% \text { wastage) }\end{array}$ & 999.63 & 999.63 \\
\hline $\begin{array}{l}\text { Cost of monitoring and } \\
\text { maintenance }\end{array}$ & $\begin{array}{l}\text { Monthly monitoring and } \\
\text { maintenance for a year }\end{array}$ & 6994.42 & 6994.42 \\
\hline Total production cost & & 8661.30 & 8661.30 \\
\hline $\begin{array}{l}\text { Average tissue growth in a } \\
\text { year }\left(\mathrm{cm}^{2}\right)(\mathrm{G})\end{array}$ & See Table 1 & 44.88 & 7.56 \\
\hline Initial tissue area $\left(\mathrm{cm}^{2}\right)(\mathrm{I})$ & See Methods & 27 & 9 \\
\hline $\begin{array}{c}\text { Amount of coral material } \\
\text { generated }(\mathrm{N})\end{array}$ & See Methods & 33 clusters & 100 fragments \\
\hline Mean survivorship (S) & See Figure 4 & 0.75 & 0.42 \\
\hline $\begin{array}{l}\text { Projected total coral tissue } \\
\text { area after } \\
1 \text { year }\left(\mathrm{cm}^{2}\right)\end{array}$ & See Methods & 1333.65 & 690.16 \\
\hline $\begin{array}{c}\text { Cost per } \mathrm{cm}^{2} \text { of coral } \\
\text { transplanted (US\$ } \mathrm{cm}^{-2} \text { ) }\end{array}$ & & 6.49 & 12.55 \\
\hline \multicolumn{4}{|c|}{$\begin{array}{l}\text { Cost estimates for collecting } 1000 \mathrm{~cm}^{2} \text { of Platygyra sinensis followed by transplanting } 100 \text { fragments }\left(9 \mathrm{~cm}^{2}\right. \\
\text { aach, with subsequent monthly monitoring and maintenance for a year. The cost per unit area was calculated } \\
\text { asing total cost of production following Toh et al. (2017) and the projected total coral tissue area (from this } \\
\text { tudy) after one year. Costs were estimated in Singapore dollars (SGD) prior to conversion to USD at the rate o } \\
\text { SGD1.33 = USD1.00. Detailed breakdown of cost estimates is provided in Supplementary Table S1. }\end{array}$} \\
\hline
\end{tabular}

\section{Discussion}

Ecological engineering is necessary and effective in augmenting biodiversity on coastal artificial structures $[16,18,52,53]$ but is relatively novel and costly [17,47-49]. It includes techniques such as retrofitting [54] and coral transplantation [55]. A growing body of work shows that coral transplantation is a viable ecological engineering approach $[17,47,49]$, but there are several unknowns to consider when increasing coral cover on artificial structures, such as the appropriate size of transplants and suitability of species. Therefore, it is important to adopt best practices from other fields including reef restoration. Here we showed that transplanting allogeneic fragments helps to hasten live coral growth and that the technique is cost-effective. We also determined that direct contact between allogeneic $P$. sinensis transplants resulted in nonfusion (i.e., formation of raised skeletal sutures without tissue necrosis). We did not observe complete fusion, which is characterised by continuous tissue and skeleton across the zone of contact $[40,41]$.

The improved growth and survivorship of the adjoining transplants may be explained by the rapid increase in coral tissue area within the cluster, conferring benefits such as increased resources to deal with stress. Our findings corroborated with studies that showed that larger fragments grew faster than smaller fragments [56-58]. As smaller fragments possess fewer resources, they are more likely to be overwhelmed by physical and environmental stresses [59] such as fragmentation and sedimentation, leading to reduced growth and survivorship. Conversely, in larger colonies, the proportion of healthy coral tissue bordering the injury generated from disturbance is greater than in smaller colonies, thus contributing to greater regeneration and consequently higher survivorship [60]. Furthermore, studies have suggested that resources could be shared between adjoining transplants upon contact, where additional energy reserves from neighbouring healthy coral polyps can help improve both tissue regeneration [60,61]. In addition, the high sediment load of Singapore's marine environment ranging between 5 to $20 \mathrm{mg} \mathrm{cm}^{-2}$ day $^{-1}$ [62], could have led to considerable stress on both adjoining and separated transplants. However, massive 
corals such as $P$. sinensis are known to be efficient in removing sedimentation through mucus $[63,64]$, ensuring access to light for optimal photosynthetic performance $[63,65,66]$. This effect is likely more pronounced amongst adjoining transplants than separated transplants due to an increase in colony size as the tissue comes into contact. Larger corals with greater energy reserves can produce more mucus and expand their tissues to remove sediment and reduce smothering $[66,67]$, hence adjoining transplants were able to both survive and grow better than the separated transplants. Our observations suggest that adjoining transplants seemed to deal better with sedimentation stress than the separated transplants. While there was no evidence of coenosarc tissue fusing between adjoining transplants, detailed studies investigating the physiological reactions between adjoining colonies could provide insights into how the growth and survivorship of these colonies are affected.

At $0.63 \pm 1.13 \mathrm{~cm}^{2} \mathrm{mth}^{-1}$, the mean monthly areal growth of $P$. sinensis transplanted separately was lower than that of another ecological engineering project in Singapore, where $P$. sinensis fragments were also transplanted apart on seawalls $\left(3.92 \pm 1.15 \mathrm{~cm}^{2} \mathrm{mth}^{-1}\right)$ [17]. The latter growth rate was more comparable to that of the adjoining transplants in our study $\left(3.74 \pm 1.58 \mathrm{~cm}^{2} \mathrm{mth}^{-1}\right)$. Although the mean initial sizes of fragments used in Toh et al. [17] were greater by approximately five times, recent work by Sam et al. [30] showed that there was no significant influence of initial fragment size on the post-transplantation growth of $P$. sinensis. The differences in growth rates could be influenced by varying local environmental conditions such as water motion and sedimentation as previous studies have reported the negative influence of high water motion $[68,69]$ and high sedimentation $[70,71]$ suppressing coral growth. Nevertheless, we demonstrated that adjoining transplants grew significantly faster than separated transplants.

High mean survivorship of adjoining P. sinensis transplants (75\%) demonstrated the suitability of this species for transplantation on seawalls. This is similar to that observed in other studies also involving $P$. sinensis being transplanted onto seawalls and monitored for between 6 and 18 months (97\% and 65\% survivorship respectively) see [17,30]. Taken together with our results, they suggest that the survivorship of transplants generally stabilises after one year, underscoring the importance of long-term monitoring ( $>1$ year) for coral transplantation. Although environmental conditions on the seawall in this study were not measured, they were likely suboptimal due to acute incidences of high sedimentation (pers. obs.). However, the higher mean survivorship of adjoining transplants compared to those transplanted separately suggests that the potential benefits exist when transplanting corals in close contact, especially in a sedimented environment.

The coral transplantation methods applied in this study are adopted from reef restoration. As reefs remain amongst one of the costliest ecosystems to restore [45], current ecological engineering techniques are likely expensive as well, however, our proposed method can reduce overall project cost. Our "what-if" scenarios showed that the overall cost per $\mathrm{cm}^{2}$ of coral transplanted could be reduced by $48.3 \%$ if transplants were adjoining to promote nonfusion, instead of being placed further apart. Rather than lowering costs by reducing manpower or materials used during the transplantation process, our approach reduces ongoing maintenance costs by ensuring higher transplant survivorship. Thus, we recommend that fragments of $P$. sinensis should be transplanted in close contact to promote nonfusion, so as to augment growth and survivorship, and consequently improve cost-effectiveness. To enhance ecological engineering outcomes, this strategy should also be tested on other coral species so that its overall effectiveness may be assessed. Findings from this study can potentially help advance coastal management, as transplanting corals on coastal artificial structures has been limited, and poses different challenges than transplantation on reefs. By transplanting coral fragments in close contact to promote nonfusion, colonies could collectively overcome the stressful conditions on seawalls, resulting in improved survivorship and growth, thus augmenting biodiversity while curtailing the project costs.

In conclusion, this study has shown that transplanting P. sinensis fragments adjoining on seawalls is potentially a practical and cost-effective ecological engineering approach. 
Additional studies are needed to verify if this technique is also applicable for other coral species, especially those with massive and foliose growth forms. Future studies should also be carried out to discern the physiological factors that have led to the increased performance of adjoining transplants.

Supplementary Materials: The following are available online at https://www.mdpi.com/article/10 $.3390 /$ jmse9121377/s1, Table S1: Detailed cost estimates of transplanting corals adjoining to promote nonfusion ("what-if" scenario 1) or separate ("what-if" scenario 2) [72].

Author Contributions: Y.P.K., C.S.L.N. and S.Q.S. conceived, designed, conducted the research and experiments, along with data analyses and wrote the manuscript. T.C.T., K.S.T., P.L.L. and L.M.C. contributed to the writing and revision of the manuscript. All authors have read and agreed to the published version of the manuscript.

Funding: This research was funded by the National Research Foundation, Prime Minister's Office, Singapore, under its Marine Science Research and Development Programme, grant number MSRDP05 (R347-000-260-281).

Institutional Review Board Statement: All applicable national and institutional guidelines for animal testing, animal care and use of animals were followed by the authors. All necessary permits for sampling and observational field studies were obtained by the authors from the National Parks Board (NParks; NP/RP17-037-2).

Informed Consent Statement: Not applicable.

Data Availability Statement: The datasets generated during the current study are available from the corresponding author on reasonable request.

Acknowledgments: We would like to thank the staff from St John's Island National Marine Laboratory for their generous assistance.

Conflicts of Interest: The authors of this study declare that they have no conflicts of interest.

\section{References}

1. Moschella, P.S.; Abbiati, M.; Åberg, P.; Airoldi, L.; Anderson, J.M.; Bacchiocchi, F.; Bulleri, F.; Dinesen, G.E.; Frost, M.; Gacia, E.; et al. Low-crested coastal defence structures as artificial habitats for marine life: Using ecological criteria in design. Coast. Eng. 2005, 52, 1053-1071. [CrossRef]

2. Dugan, J.E.; Airoldi, L.; Chapman, M.G.; Walker, S.J.; Schlacher, T.; Wolanski, E.; McLusky, D. Estuarine and coastal structures: Environmental effects, a focus on shore and nearshore structures. Treatise Estuar. Coast. Sci. 2011, 8, 17-41.

3. French, P.W. Coastal Defences: Processes, Problems and Solutions; Routledge: Oxfordshire, UK, 2002; pp. 384-390.

4. Bulleri, F.; Chapman, M.G. The introduction of coastal infrastructure as a driver of change in marine environments. J. Appl. Ecol. 2010, 47, 26-35. [CrossRef]

5. Moreira, J.; Chapman, M.G.; Underwood, A.J. Maintenance of chitons on seawalls using crevices on sandstone blocks as habitat in Sydney Harbour, Australia. J. Exp. Mar. Biol. Ecol. 2007, 347, 134-143. [CrossRef]

6. Viyakarn, V.; Chavanich, S.; Raksasab, C.; Loyjiw, T. New coral community on a breakwater in Thailand. Coral Reefs 2009, $28,427$. [CrossRef]

7. Chou, L.M.; Ng, C.S.L.; Chan, J.S.M.; Seow, L.A. Natural coral colonization of a marina seawall in Singapore. J. Coast. Dev. 2010, $14,11-17$.

8. Kikuzawa, Y.P.; Ng, C.S.L.; Toh, T.C.; Sam, S.Q.; Lee, Y.L.; Loo, P.L.; Chua, Y.Z.; Tan, K.S.; Chou, L.M. Diversity of subtidal benthic and hard coral communities on sloping and vertical seawalls in Singapore. Mar. Biodivers. 2020, 50, 95. [CrossRef]

9. Ng, C.S.L.; Chan, Y.K.S.; Nguyen, N.T.H.; Kikuzawa, Y.P.; Sam, S.Q.; Toh, T.C.; Mock, A.Y.J.; Chou, L.M.; Huang, D. Coral community composition and carbonate production in an urbanized seascape. Mar. Environ. Res. 2021, 168, 105322. [CrossRef]

10. Burt, J.; Bartholomew, A.; Usseglio, P.; Bauman, A.; Sale, P.F. Are artificial reefs surrogates of natural habitats for corals and fish in Dubai United Arab Emirates? Coral Reefs 2009, 28, 663-675. [CrossRef]

11. Cenci, E.; Pizzolon, M.; Chimento, N.; Mazzoldi, C. The influence of a new artificial structure on fish assemblages of adjacent hard substrata. Estuar. Coast. Shelf Sci. 2011, 91, 133-149. [CrossRef]

12. Taira, D.; Poquita-Du, R.C.; Toh, T.C.; Toh, K.B.; Ng, C.S.L.; Afiq-Rosli, L.; Chou, L.M.; Song, T. Spatial variability of fish communities in a highly urbanised reef system. Urban. Ecosyst. 2018, 21, 85-95. [CrossRef]

13. Chapman, M.G.; Bulleri, F. Intertidal seawalls-New features of landscape in intertidal environments. Landsc. Urban Plan. 2003, 62, 159-172. [CrossRef]

14. Chapman, M.G. Paucity of mobile species on constructed seawalls: Effects of urbanization on biodiversity. Mar. Ecol. Prog. Ser. 2003, 264, 21-29. [CrossRef] 
15. Lai, S.; Loke, L.H.; Hilton, M.J.; Bouma, T.J.; Todd, P.A. The effects of urbanisation on coastal habitats and the potential for ecological engineering: A Singapore case study. Ocean Coast. Manag. 2015, 103, 78-85. [CrossRef]

16. Rachmilovitz, E.N.; Rinkevich, B. Tiling the reef-Exploring the first step of an ecological engineering tool that may promote phase-shift reversals in coral reefs. Ecol. Eng. 2017, 105, 150-161. [CrossRef]

17. Toh, T.C.; Ng, C.S.L.; Loke, H.X.; Taira, D.; Toh, K.B.; Afiq-Rosli, L.; Du, R.C.P.; Cabaitan, P.; Sam, S.Q.; Kikuzawa, Y.P.; et al. A cost-effective approach to enhance scleractinian diversity on artificial shorelines. Ecol. Eng. 2017, 99, 349-357. [CrossRef]

18. Rinkevich, B. Ecological engineering approaches in coral reef restoration. ICES J. Mar. Sci. 2021, 78, 410-420. [CrossRef]

19. Ng, C.S.L.; Lim, S.C.; Ong, J.Y.; Teo, L.M.S.; Chou, L.M.; Chua, K.E.; Tan, K.S. Enhancing the biodiversity of coastal defence structures: Transplantation of nursery-reared reef biota onto intertidal seawalls. Ecol. Eng. 2015, 82, 480-486. [CrossRef]

20. Edwards, A.J.; Clark, S. Coral transplantation: A useful management tool or misguided meddling? Mar. Pollut. Bull. 1999, 37, 474-487. [CrossRef]

21. Boström-Einarsson, L.; Babcock, R.C.; Bayraktarov, E.; Ceccarelli, D.; Cook, N.; Ferse, S.C.; Hancock, B.; Harrison, P.; Hein, M.; Shaver, E.; et al. Coral restoration-A systematic review of current methods, successes, failures and future directions. PLoS ONE 2020, 15, e0226631.

22. Page, C.A.; Muller, E.M.; Vaughan, D.E. Microfragmenting for the successful restoration of slow growing massive corals. Ecol. Eng. 2018, 123, 86-94. [CrossRef]

23. Baldock, T.E.; Karampour, H.; Sleep, R.; Vyltla, A.; Albermani, F.; Golshani, A.; Callaghan, D.P.; Roff, G.; Mumby, P.J. Resilience of branching and massive corals to wave loading under sea level rise-A coupled computational fluid dynamics-structural analysis. Mar. Pollut. Bull. 2014, 86, 91-101. [CrossRef]

24. Zakai, D.; Chadwick-Furman, N.E. Impacts of intensive recreational diving on reef corals at Eilat, northern Red Sea. Biol. Conserv. 2002, 105, 179-187. [CrossRef]

25. Pratchett, M.S.; McCowan, D.; Maynard, J.A.; Heron, S.F. Changes in bleaching susceptibility among corals subject to ocean warming and recurrent bleaching in Moorea, French Polynesia. PLoS ONE 2013, 8, e70443. [CrossRef]

26. Penin, L.; Vidal-Dupiol, J.; Adjeroud, M. Response of coral assemblages to thermal stress: Are bleaching intensity and spatial patterns consistent between events? Environ. Monit. Assess. 2013, 185, 5031-5042. [CrossRef] [PubMed]

27. Baker, A.C.; Glynn, P.W.; Riegl, B. Climate change and coral reef bleaching: An ecological assessment of long-term impacts, recovery trends and future outlook. Estuar. Coast. Shelf. Sci. 2008, 80, 435-471. [CrossRef]

28. Shaish, L.; Levy, G.; Katzir, G.; Rinkevich, B. Employing a highly fragmented, weedy coral species in reef restoration. Ecol. Eng. 2010, 36, 1424-1432. [CrossRef]

29. Bowden-Kerby, A. Restoration of threatened Acropora cervicornis corals: Intraspecific variation as a factor in mortality, growth, and self-attachment. In Proceedings of the 11th International Coral Reef Symposium, Fort Lauderdale, FL, USA, 7-11 July 2008; Nova Southeastern University: Fort Lauderdale, FL, USA, 2008; Volume 2, pp. 1194-1198.

30. Sam, S.Q.; Ng, C.S.L.; Kikuzawa, Y.P.; Toh, T.C.; Sim, W.T.; Chou, L.M. Influence of fragment size on post transplantation growth and survival of domed scleractinian corals. Mar. Biol. Res. 2021, 17, 327-340. [CrossRef]

31. Blockley, D.J. Effect of wharves on intertidal assemblages on seawalls in Sydney Harbour, Australia. Mar. Environ. Res. 2007, 63, 409-427. [CrossRef] [PubMed]

32. Zhao, K.; Yuan, J.; Loke, L.H.; Chan, S.H.; Todd, P.A.; Liu, P.L.F. Modelling surface temperature of granite seawalls in Singapore. Case Stud. Therm. Eng. 2019, 13, 100395. [CrossRef]

33. Kamphuis, J.W. Computation of coastal morphology. In Proceedings of the 23rd International Conference on Coastal Engineering, Venice, Italy, 4-9 October 1992; American Society of Civil Engineers: Reston, VA, USA, 1992; pp. 211-257.

34. Anand, K.V.; Sundar, V.; Sannasiraj, S.A. Hydrodynamic characteristics of curved-front seawall models compared with vertical seawall under regular waves. J. Coast. Res. 2011, 27, 1103-1112. [CrossRef]

35. Ng, C.S.L.; Chen, D.; Chou, L.M. Hard Coral Assemblages on Seawalls in Singapore. In Contributions to Marine Science; Tan, K.S., Ed.; National University of Singapore: Singapore, 2012; pp. 75-79.

36. Suggett, D.J.; Camp, E.F.; Edmondson, J.; Boström-Einarsson, L.; Ramler, V.; Lohr, K.; Patterson, J.T. Optimizing return-on-effort for coral nursery and outplanting practices to aid restoration of the Great Barrier Reef. Restor. Ecol. 2019, 27, 683-693. [CrossRef]

37. Forsman, Z.H.; Page, C.A.; Toonen, R.J.; Vaughan, D. Growing coral larger and faster: Micro-colony-fusion as a strategy for accelerating coral cover. Peer] 2015, 3, 1313. [CrossRef]

38. Raymundo, L.J.; Maypa, A.P. Getting bigger faster: Mediation of size-specific mortality via fusion in juvenile coral transplants. Ecol. Appl. 2004, 14, 281-295. [CrossRef]

39. Amar, K.O.; Rinkevich, B. Mounting of erratic histoincompatible responses in hermatypic corals: A multi-year interval comparison. J. Exp. Biol. 2010, 213, 535-540. [CrossRef] [PubMed]

40. Hidaka, M.; Yurugi, K.; Sunagawa, S.; Kinzie Iii, R.A. Contact reactions between young colonies of the coral Pocillopora damicornis. Coral Reefs 1997, 16, 13-20. [CrossRef]

41. Chadwick-Furman, N.; Rinkevich, B. A complex allorecognition system in a reef-building coral: Delayed responses, reversals and nontransitive hierarchies. Coral Reefs 1994, 13, 57-63. [CrossRef]

42. Puill-Stephan, E.; Willis, B.L.; Abrego, D. Allorecognition maturation in the broadcast-spawning coral Acropora millepora. Coral Reefs 2012, 31, 1019-1028. [CrossRef] 
43. Huffmyer, A.S.; Drury, C.; Majerová, E.; Lemus, J.D.; Gates, R.D. Tissue fusion and enhanced genotypic diversity support the survival of Pocillopora acuta coral recruits under thermal stress. Coral Reefs 2021, 40, 447-458. [CrossRef]

44. Toh, T.C.; Ng, C.S.L.; Peh, J.W.K.; Toh, K.B.; Chou, L.M. Augmenting the post-transplantation growth and survivorship of juvenile scleractinian corals via nutritional enhancement. PLOS ONE 2014, 9, e98529.

45. Bayraktarov, E.; Saunders, M.I.; Abdullah, S.; Mills, M.; Beher, J.; Possingham, H.P.; Mumby, P.J.; Lovelock, C.E. The cost and feasibility of marine coastal restoration. Ecol. Appl. 2016, 26, 1055-1074. [CrossRef] [PubMed]

46. Spurgeon, J.P.; Lindahl, U. Economics of Coral Reef Restoration-Collected Essays on the Economics of Coral Reefs; Cordio Kalmar University: Kalmar, Sweden, 2002; pp. 125-136.

47. Burt, J.A.; Bartholomew, A. Towards more sustainable coastal development in the Arabian Gulf: Opportunities for ecological engineering in an urbanized seascape. Mar. Pollut. Bull. 2019, 142, 93-102. [CrossRef]

48. Taira, D.; Heery, E.C.; Loke, L.H.; Teo, A.; Bauman, A.G.; Todd, P.A. Ecological engineering across organismal scales: Trophicmediated positive effects of microhabitat enhancement on fishes. Mar Ecol. Prog. Ser. 2020, 656, 181-192. [CrossRef]

49. Golomb, D.; Shashar, N.; Rinkevich, B. Coral carpets-a novel ecological engineering tool aimed at constructing coral communities on soft sand bottoms. Ecol. Eng. 2020, 145, 105743. [CrossRef]

50. Possingham, H.P.; Bode, M.; Klein, C.J. Optimal conservation outcomes require both restoration and protection. PLoS Biol. 2015, 13, e1002052. [CrossRef]

51. Kikuzawa, Y.P.; Toh, T.C.; Ng, C.S.L.; Sam, S.Q.; Taira, D.; Afiq-Rosli, L.; Chou, L.M. Quantifying growth in maricultured corals using photogrammetry. Aquac. Res. 2018, 49, 2249-2255. [CrossRef]

52. Rosenzweig, M.L. Reconciliation ecology and the future of species diversity. Oryx 2003, 37, 194-205. [CrossRef]

53. Browne, M.A.; Chapman, M.G. Ecologically informed engineering reduces loss of intertidal biodiversity on artificial shorelines. Environ. Sci. Technol. 2011, 45, 8204-8207. [CrossRef] [PubMed]

54. Loke, L.H.; Todd, P.A. Structural complexity and component type increase intertidal biodiversity independently of area. Ecology 2016, 97, 383-393. [CrossRef]

55. Clark, S.; Edwards, A.J. Coral transplantation as an aid to reef rehabilitation: Evaluation of a case study in the Maldives Islands. Coral Reefs 1995, 14, 201-213. [CrossRef]

56. Lirman, D.; Thyberg, T.; Herlan, J.; Hill, C.; Young-Lahiff, C.; Schopmeyer, S.; Huntington, B.; Santos, R.; Drury, C. Propagation of the threatened staghorn coral Acropora cervicornis: Methods to minimize the impacts of fragment collection and maximize production. Coral Reefs 2010, 29, 729-735. [CrossRef]

57. Lirman, D.; Schopmeyer, S.; Galvan, V.; Drury, C.; Baker, A.C.; Baums, I.B. Growth dynamics of the threatened Caribbean staghorn coral Acropora cervicornis: Influence of host genotype, symbiont identity, colony size, and environmental setting. PLoS ONE 2014, 9, e107253.

58. Lizcano-Sandoval, L.D.; Londoño-Cruz, E.; Zapata, F.A. Growth and survival of Pocillopora damicornis (Scleractinia: Pocilloporidae) coral fragments and their potential for coral reef restoration in the Tropical Eastern Pacific. Mar. Biol. Res. 2018, 14, 887-897. [CrossRef]

59. Meesters, E.H.; Wesseling, I.; Bak, R.P. Partial mortality in three species of reef-building corals and the relation with colony morphology. Bull. Mar. Sci. 1996, 58, 838-852.

60. Bak, R.P.M. Neoplasia, regeneration and growth in the reef-building coral Acropora palmata. Mar. Biol. 1983, 77, 221-227. [CrossRef]

61. Meesters, E.H.; Bos, A.; Gast, G.J. Effects of sedimentation and lesion position on coral tissue regeneration. In Proceedings of the Seventh International Coral Reef Symposium, Guam, Micronesia, 22-27 June 1992; University of Guam Press: Mangilao, GU, USA; Volume 2, pp. 671-678.

62. Dikou, A.; Van Woesik, R. Survival under chronic stress from sediment load: Spatial patterns of hard coral communities in the southern islands of Singapore. Mar. Pollut. Bull. 2006, 52, 1340-1354. [CrossRef]

63. Browne, N.K.; Precht, E.; Last, K.S.; Todd, P.A. Photo-physiological costs associated with acute sediment stress events in three near-shore turbid water corals. Mar. Ecol. Prog. Ser. 2014, 502, 129-143. [CrossRef]

64. Browne, N.K.; Tay, J.; Todd, P.A. Recreating pulsed turbidity events to determine coral-sediment thresholds for active management. J. Exp. Mar. Biol. Ecol. 2015, 466, 98-109. [CrossRef]

65. Falkowski, P.G.; Jokiel, P.L.; Kinzie, R.A. Irradiance and Corals; Elsevier: Amsterdam, The Netherlands, 1990; Volume 25, pp. 89-107.

66. Erftemeijer, P.L.; Riegl, B.; Hoeksema, B.W.; Todd, P.A. Environmental impacts of dredging and other sediment disturbances on corals: A review. Mar. Pollut. Bull. 2012, 64, 1737-1765. [CrossRef]

67. Gilmour, J.P. Acute sedimentation causes size-specific mortality and asexual budding in the mushroom coral, Fungia fungites. Mar. Freshw. Res. 2002, 53, 805-812. [CrossRef]

68. Forsman, Z.H.; Kimokeo, B.K.; Bird, C.E.; Hunter, C.L.; Toonen, R.J. Coral farming: Effects of light, water motion and artificial foods. J. Mar. Biolog. 2012, 92, 721-729. [CrossRef]

69. Sebens, K.P.; Witting, J.; Helmuth, B. Effects of water flow and branch spacing on particle capture by the reef coral Madracis mirabilis (Duchassaing and Michelotti). J. Exp. Mar. 1997, 211, 1-28. [CrossRef]

70. DeMartini, E.; Jokiel, P.; Beets, J.; Stender, Y.; Storlazzi, C.; Minton, D.; Conklin, E. Terrigenous sediment impact on coral recruitment and growth affects the use of coral habitat by recruit parrotfishes (F. Scaridae). J. Coast. Conserv. 2013, 17, 417-429. [CrossRef] 
71. Nugues, M.M.; Roberts, C.M. Coral mortality and interaction with algae in relation to sedimentation. Coral Reefs 2003, 22, 507-516. [CrossRef]

72. Edwards, A.J. Reef Rehabilitation Manual; Coral Reef Targeted Research \& Capacity Building for Management Program: St. Lucia, Australia, 2010; pp. 1-166. 